\title{
Sequencing and quantifying plastid DNA fragments stored in sapwood and heartwood of Torreya nucifera
}

\author{
Ugai Watanabe $^{1} \cdot$ Hisashi Abe $^{2}$
}

Received: 8 September 2016 / Accepted: 7 January 2017 / Published online: 28 February 2017

(C) The Japan Wood Research Society 2017

\begin{abstract}
The selection of wood species and the styles of sculpture play key roles in the characterization of Buddhist statues. After Jianzhen, a Chinese Buddhist monk, visited Japan in the mid-eighth century, wood of the genus Torreya had been frequently used to produce single-bole statues. Establishing measures for the accurate identification of wood in the genus Torreya is effective for investigating the drastic change in the production of statues during this period. Analyzing the plastid deoxyribonucleic acid (DNA) fragments extracted from wood is considered helpful in the identification of species in the same genus. This study analyzed the sequences and residual amounts of plastid DNA fragments in the wood of Torreya nucifera. Nucleotide substitutions in the plastid DNA were clearly identified between $T$. nucifera and the species distributed in China, indicating that the wood of Torreya sp. can be discriminated based on the plastid DNA sequences. DNA polymorphism analyses revealed sequence diversity for the intergenic spacers on the T. nucifera plastid DNA. A series of polymerase chain reaction (PCR) analyses demonstrated that the plastid DNA fragments with a length of approximately $100 \mathrm{bp}$ could be amplified from the residual DNA extracted from the T. nucifera sapwood with longer elapsed years after cutting. Therefore, an identification of wood
\end{abstract}

A part of this work was presented at the 66th Annual Meeting of Japan Wood Research Society, Nagoya, Japan, March 2016.

Ugai Watanabe

ugai.watanabe@it-chiba.ac.jp

1 Faculty of Advanced Engineering, Chiba Institute of Technology, Tsudanuma, Narashino, Chiba 275-0016, Japan

2 Forestry and Forest Products Research Institute, Tsukuba, Ibaraki 305-8687, Japan species in the genus Torreya based on their plastid DNA is considered to be one of the most effective measures taken in the study regarding the historical changes of Buddhist statues.

Keywords DNA · Plastid - Torreya $\cdot$ Wood identification

\section{Introduction}

The genus Torreya belongs to the family Taxaceae, and consists of six species worldwide. In Asia, Torreya nucifera Siebold \& Zucc. is distributed on the Honshu, Shikoku, and Kyushu islands of Japan, and in Jeju and on the Wando islands of South Korea [1]. T. nucifera is a big tree up to $25 \mathrm{~m}$ tall, with a trunk measuring $2 \mathrm{~m}$ d.b.h, and grows scattered in mixed conifer and hardwood forests [2]. In China, three species are distributed: T. fargesii Franch. mainly in Chongqing, Hubei, Hunan, Jiangxi, Shaanxi, and Sichuan; T. grandis Fortune ex Lindl. mainly in Anhui, Fujian, Guizhou, Hunan, Jiangsu, Jiangxi, and Zhejiang; and T. jackii Chun. in Fujian Jiangxi and Zhejiang [2]. The wood of this genus is moderately hard and durable, and silky in texture. The grain is fine and fairly even.

In Japan, the wood of Torreya sp. played an important part in the history of Buddhism; woods of this genus were frequently used for Buddhist statues made in the eighth and ninth centuries $[3,4]$. Many statues in this period were carved from the single stem of a tree of Torreya sp., a peculiar characteristic of them. In the seventh century, the wood of Cinnamomum sp. was used for many Buddhist statues, that is, the wood species used for statues suddenly changed from hardwood to softwood in the eighth century. This major change in wood material might be needed to produce the single-bole statues using sophisticated techniques 
during that period. However, a question still remains about the process of transition to the production of Buddhist statues in the eighth century, that is, how the wood of Torreya sp. was introduced into the production of single-bole statues. Researchers who study Buddhist statues infer that Jianzhen, a Chinese Buddhist monk, influenced the major change in the styles of wooden statues after the eighth century [3]. Therefore, to clearly answer the question about the Buddhist statues produced in the eighth century, it is essential to identify the wood species used for the statues in the genus Torreya distributed in Japan and China.

As the tracheids of Torreya sp. demonstrate their characteristic helical thickening on the inner surfaces of the walls [5], wood of this species can be easily distinguished from other coniferous woods using a microscope. However, an anatomical investigation cannot identify the wood species in the genus Torreya. Generally, it is difficult to precisely identify wood species at the species level by microscopic observation [6]. For the identification of wood at the species level, a multiple approach using a number of analyzing methods must be adopted. The genomic deoxyribonucleic acid (DNA) stored in wood includes the nucleotide sequences inherent in its species. Several studies have proved the effectiveness of DNA identification of wood materials that are difficult to distinguish based on anatomical features [7-13]. This method is also expected to function in identifying the woods used as the materials of historically valuable products and buildings. The characteristics of Buddhist statues and their changes strongly relate to the history of Buddhist beliefs. Especially, the production of single-bole statues in the eighth century is speculated to be a major turning point in the history of Buddhist statues. Accurate identification of wood species in the genus Torreya based on DNA barcoding can contribute to clarify the transition process of Buddhist statues during this period.

More copies of plastid DNA exist in wood than nuclear DNA since plant cells generally possess a number of plastids. On the other hand, the residual DNA in old wood is considered to be fragmented or degraded for long elapsed years after cutting. Therefore, estimating the properties of plastid DNA fragments stored in the wood of Torreya sp., such as the nucleotide substitutions and residual amounts, is of particular importance in establishing a measure for identifying the species used for the Buddhist statues produced in the eighth and ninth centuries. In this study, the sequences and residual copy numbers of plastid DNA stored in the wood of T. nucifera were analyzed to consider the accurate identification of wood species in the genus Torreya distributed in Japan and China.

\section{Materials and methods}

\section{Wood materials}

Sapwood and heartwood of $T$. nucifera were selected from the collections of xylariums of the Forestry and Forest Products Research Institute. Table 1 lists the material names, parts, elapsed years after cutting, the Wood ID Nos., and sampling location for all materials.

\section{Preparation of wood powder and extraction of residual DNA}

Small pieces of $1 \mathrm{~mm} \times 1 \mathrm{~mm} \times 5 \mathrm{~mm}$ were prepared from each material listed in Table 1. After being pre-cooled in liquid nitrogen, the materials were powdered with a disruptor (Multi-Beads Shocker, Yasui Kikai). The revolution speed was $2500 \mathrm{rpm}$ for a milling time of $30 \mathrm{~s}$. All wood powder samples were prepared in 2014, and then stored at temperatures below $-80^{\circ} \mathrm{C}$ just prior to the extraction of residual DNA.

The residual DNA contained in $500 \mathrm{mg}$ of each wood powder was extracted using the DNeasy Plant Maxi Kit and Mini Kit (Qiagen), and then finally eluted in $50 \mu \mathrm{l}$ of ultrapure water. The concentrations of DNA extracted were measured using a fluorometer (Qubit 2.0, Life Technologies). The extracting operation was conducted twice for each wood powder sample.
Table 1 Wood materials for extraction of residual deoxyribonucleic acid (DNA)

\begin{tabular}{lllll}
\hline Material name & Part & $\begin{array}{l}\text { Elapsed years } \\
\text { after cutting }\end{array}$ & Wood ID no. & Sampling location \\
\hline $12-\mathrm{S}$ & Sapwood & 12 & TWTw19683 & Kamitsusima, Nagasaki Pref \\
$12-\mathrm{H}$ & Heartwood & 12 & TWTw19683 & Kamitsusima, Nagasaki Pref \\
$50-\mathrm{S}$ & Sapwood & 50 & TWTw14506 & Hachioji, Tokyo \\
$50-\mathrm{H}$ & Heartwood & 50 & TWTw14506 & Hachioji, Tokyo \\
$63-\mathrm{S}$ & Sapwood & 63 & TWTw26856 & Tokyo \\
$63-\mathrm{H}$ & Heartwood & 63 & TWTw26856 & Tokyo \\
$85-\mathrm{S}$ & Sapwood & 85 & TWTw3321 & Kamogawa, Chiba Pref \\
$85-\mathrm{H}$ & Heartwood & 85 & TWTw3321 & Kamogawa, Chiba Pref \\
\hline
\end{tabular}




\section{Detection and sequencing of plastid DNA fragments}

The partial sequences of $r b c L$ (accession No. JQ512623, nucleotide positions 190 to 559), trnL-trnF (EF660644, 568 to 939), and psbA-trnH (EF660697, 269 to 647) were amplified from the residual DNA extracted by polymerase chain reaction (PCR). Table 2 lists the sense and anti-sense primer sequences used for the amplification. The PCR enzyme and buffer solution used were the TaKaRa ExTaqTM HotStart version (Takara Bio Inc.) and Ampdirect ${ }^{\circledR}$ Plus (Shimadzu Corporation), respectively. The reaction mixtures contained 5\% extracted DNA (volume), 0.025 unit/ $\mu$ l PCR enzyme, and $0.5 \mu \mathrm{M}$ sense and anti-sense primers. Amplifications were performed with an initial denaturation at $98.0^{\circ} \mathrm{C}$ for $10 \mathrm{~min}$, followed by 40 cycles of denaturation at $98.0^{\circ} \mathrm{C}$ for $10 \mathrm{~s}$, annealing at $55.5^{\circ} \mathrm{C}(r b c L), 53.7^{\circ} \mathrm{C}(t r n L-t r n F)$, and $60.0^{\circ} \mathrm{C}$ (psbA$\operatorname{trn} H$ ) for $30 \mathrm{~s}$, and then extension at $72.0^{\circ} \mathrm{C}$ for $25 \mathrm{~s}$. The amplicons were detected by $3 \%$ agarose gel electrophoresis with ethidium bromide. The nucleotide sequences of amplicons were analyzed to investigate the nucleotide substitutions. For the sequences of trnL-trnF and $p s b A$ trnH obtained, DNA polymorphism analyses were conducted to estimate the nucleotide diversity with DnaSP Ver. 5.10.01 [14]. The sequences analyzed were also compared with the corresponding sequences of Torreya spp. in China as contained in the National Center for Biotechnology Information (NCBI): NC_029398:54797-56248 $(r b c L), \quad$ NC_029398:47089-48078 (trnL-trnF), and NC_029398:136480-137075 (psbA-trnH) for T. fargesii, DQ478794 (rbcL); EF660623 (trnL-trnF) and EF660692 (psbA-trnH) for T. grandis; KJ589006 (rbcL), KJ589075 ( $\operatorname{trnL}$-trnF), and EF660693 (psbA-trnH) for T. jackii.

\section{Quantitative PCR analysis of residual plastid DNA}

The copy numbers of targeted DNA fragments of $r b c L$, trnL-trnF, and $p s b A$-trnH in the extracted residual DNA were investigated using quantitative PCR (qPCR) analyses. The same equipment, amplification protocol, and estimating method as previously reported were adopted in this study [15]. Table 3 lists the amplicon lengths, sense and anti-sense primer sequences, and $\mathrm{TaqMan}^{\circledR}$ probe sequences (Dual-labeled probe and primers for QPCR, Sigma Aldrich Japan) for the three targeted regions. The DNA fragments amplified using the sense and anti-sense primers listed in Table 2 are purified (QIAquick Gel Extraction Kit, Qiagen) and then used to prepare 1:10 dilution series for a standard curve method. The initial copy numbers of the dilution series were as follows: with $r b c L$, $2.57 \times 10^{6}$ copies per $\mu$ l, with $t r n L-t r n F, 3.06 \times 10^{6}$ copies per $\mu$, and with $p s b A$-trnH, $3.81 \times 10^{6}$ copies per $\mu$ l. The PCR efficiency of each measurement was determined from the amplification curves of the dilution series obtained. Experimental data with 85 to $95 \%$ of the efficiencies were used to estimate the copy numbers of targeted sequences

Table 2 Sequences of sense primers and anti-sense primers for the polymerase chain reaction (PCR)

\begin{tabular}{llll}
\hline Target & $\begin{array}{l}\text { Amplicon } \\
\text { length }(\mathrm{bp})\end{array}$ & Sense primer & Anti-sense primer \\
\hline$r b c L$ & 370 & GGTACATGGACCACTGTTTG (nucleotide positions & TACCATAATTCTTGGCGGAT (nucleotide positions \\
& & 190-208) & $559-540$ ) \\
trnL-trnF & 372 & CTTTTCATAATTCTGTGAGCAA (nucleotide positions & GTCCTCTGCTCTACCAACTG (nucleotide positions \\
& & $568-589)$ & 939-920) \\
psbA-trnH & 379 & TTCAGCTATGGATGCTAAATAAAGC (nucleotide & CGCATGGTGGATTCACAATCC (nucleotide positions \\
& & positions 269-293) & 647-627) \\
\hline
\end{tabular}

Table 3 Sequences of sense primers, anti-sense primers, and probes for the quantitative polymerase chain reaction (PCR) analyses

\begin{tabular}{|c|c|c|c|c|}
\hline Target & $\begin{array}{l}\text { Amplicon } \\
\text { length } \\
\text { (bp) }\end{array}$ & Sense primer & Anti-sense primer & Probe \\
\hline$r b c L$ & 99 & $\begin{array}{l}\text { TTACCAGTCTTGATCGTTACA } \\
\text { AGG (nucleotide positions 221- } \\
\text { 244) }\end{array}$ & $\begin{array}{l}\text { GATCTAAAGGGTAAGCTACAT } \\
\text { AGGC (nucleotide positions 319- } \\
\text { 295) }\end{array}$ & $\begin{array}{l}\text { CCAGGAACGGGCTCAATATCA } \\
\text { TAGCATCG (nucleotide positions } \\
275-247 \text { ) }\end{array}$ \\
\hline $\operatorname{trn} L-\operatorname{trn} F$ & 111 & $\begin{array}{l}\text { CGGAATTCTCACTTTATTTTA } \\
\text { AATAGCGC (nucleotide positions } \\
592-620 \text { ) }\end{array}$ & $\begin{array}{l}\text { CAATTGCTCCTACGATCAACT } \\
\text { TGTC (nucleotide positions 702- } \\
678 \text { ) }\end{array}$ & $\begin{array}{l}\text { ACCCCACTATTTTTTGCTAAATAG } \\
\text { CAAAATAGATC (nucleotide posi- } \\
\text { tions 639-673) }\end{array}$ \\
\hline psbA-trnH & 93 & $\begin{array}{l}\text { CTTGGAAGGAATGACCGT } \\
\text { AGACA (nucleotide positions } \\
555-577 \text { ) }\end{array}$ & $\begin{array}{l}\text { CGCATGGTGGATTCACAATCC } \\
\text { (nucleotide positions 647-627) }\end{array}$ & $\begin{array}{l}\text { CCTTTGAACCACTTGGCTACGTCC } \\
\text { GC (nucleotide positions 622-597) }\end{array}$ \\
\hline
\end{tabular}


in the residual DNA extracted. The correlation coefficients of the standard curves in this experiment were very high $\left(r^{2}=0.99\right)$, indicating that the primers and probes listed in Table 3 functioned precisely.

\section{Results and discussion}

\section{Amount of total DNA extracted from the samples}

Residual DNA was not detected from the samples using a fluorometer, except 12-S and 12-H. The amounts of total DNA extracted from $12-\mathrm{S}$ were $645 \mathrm{ng} / 500 \mathrm{mg}$ and $650 \mathrm{ng}$ $1500 \mathrm{mg}$. For $12-\mathrm{H}$, the amounts were $6.0 \mathrm{ng} / 500 \mathrm{mg}$ and $8.5 \mathrm{ng} / 500 \mathrm{mg}$. The values for $12-\mathrm{S}$ were larger than those obtained in the previous study for Cryptomeria japonica sapwood [15]. The values for $12-\mathrm{H}$ were almost the same as those for $C$. japonica heartwood.

\section{PCR amplifications and sequencing}

Figure 1 shows the PCR amplifications of the 370 bp $r b c L$ fragment, 372 bp trnL-trnF fragment, and 379 bp psbA$\operatorname{trn} H$ fragment contained in the samples. The three fragments were amplified from $12-\mathrm{S}, 12-\mathrm{H}, 63-\mathrm{H}$, and $85-\mathrm{S}$. Additionally, the trnL-trnF and psbA-trnH fragments were amplified from 50-H. Slight or no amplification was observed for 50-S, 63-S, and 85-H, indicating that for these samples the plastid DNA was largely fragmented or that it was difficult to amplify the residual DNA.

12-S 50-S 63-S 85-S 12-H 50-H 63-H 85-H

a

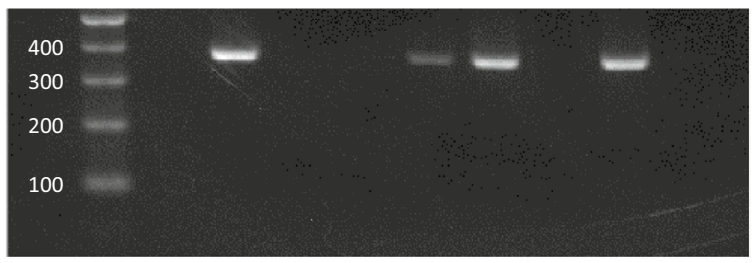

b

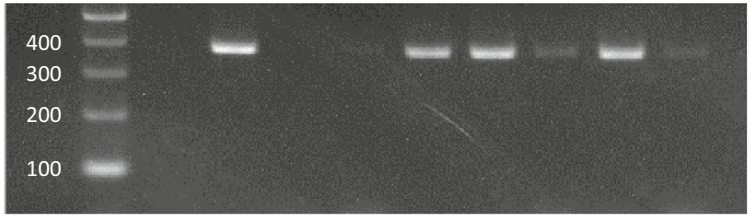

C

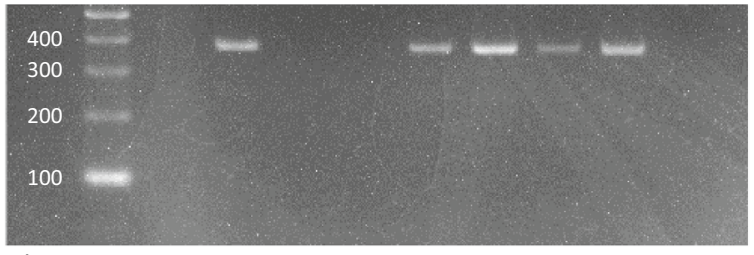

$b p$

Fig. 1 Gel electrophoresis of amplified plastid DNA fragments of $T$. nucifera. arbcL, btrnL-trnF, $\mathbf{c} p s b A-t r n H$
For the fragments amplified from $12-\mathrm{S}, 12-\mathrm{H}, 63-\mathrm{H}$, and $85-\mathrm{S}$, the nucleotide sequences were analyzed and compared to each other. These were also compared with the corresponding sequences of Torreya spp. distributed in China. Table 4 lists the nucleotide substitutions and deletions in the three fragments for T. nucifera and three Chinese Torreya spp. There was a nucleotide transition at position 247 in T. nucifera rbcL. T. nucifera is discriminated from T. fargesii and $T$. grandis with the difference in nucleotide at one position. Sequencing the amplified T. nucifera trnL$\operatorname{trn} F$ fragments revealed that the length was one nucleotide longer than the corresponding sequence on EF660644. There were two nucleotide transitions at positions 600 and 681 in this sequence. The three Chinese Torreya spp. lack a nucleotide at position 752 . The differences in nucleotides at four positions as well as the one deletion enable T. nucifera to be distinguished from the Chinese Torreya spp. No nucleotide substitution was observed within the four fragments of T. nucifera psbA-trnH. For this sequence, there are more differences and deletions in nucleotides than the other two sequences, thereby enabling a clearer distinction between T. nucifera and the Chinese Torreya spp.

This experiment analyzed the 1122 nucleotide sequences in T. nucifera plastid DNA. These are approximately $0.9 \%$ of whole plastid genome DNA sequences in reference to previous studies on conifers [16, 17]. As shown in Table 4, there are at least 21 nucleotide substitutions among the four Torreya spp. in Japan and China. Nucleotide substitution in the plastid genome provides the key base for wood identification at the species level. In Cyclobalanopsis, a subgenus of Quercus, nucleotide substitutions and insertion/deletion were detected at four positions in the $151 \mathrm{bp} \operatorname{trnT}$-trnL fragment [7]. Between $Q$. rubra and $Q$. robur, there were five nucleotide insertions/deletions at the A/T-repeat region in the $290 \mathrm{bp} \operatorname{trn} D$-trnT fragment [8]. The five nucleotide transitions and two transversions in the 441 bp trnL-trnF fragment were observed among four wood groups of Shorea spp [9]. Nucleotide substitutions of plastid DNA among the four Torreya spp. in Japan and China were detected at the almost same frequency with the species mentioned above, indicating that detecting appropriate regions in the plastid DNA was also effective for identifying wood in the genus Torreya.

Sequencing the amplified plastid DNA fragments revealed nucleotide substitutions among the three individuals of $T$. nucifera. The nucleotide diversity for the combined sequence of $\operatorname{trn} L$-trnF and $p s b A$-trnH was estimated to be $1.8 \times 10^{-3}$ [Standard deviation (SD) $0.84 \times 10^{-3}$ ]. For the trnL-trnF fragment, the nucleotide diversity was estimated to be $3.6 \times 10^{-3}$ (SD $1.7 \times 10^{-3}$ ). These values show the sequence diversity of the intergenic spacers on the $T$. nucifera plastid DNA. More sequence data for this plastid DNA should be collected from various areas in Japan, 
Table 4 Nucleotide substitutions and deletions in the three fragments for T. nucifera and three Chinese Torreya spp.

\begin{tabular}{|c|c|c|c|c|c|c|c|c|c|c|c|c|c|c|c|c|}
\hline \multirow[t]{2}{*}{ Sample } & \multicolumn{2}{|c|}{$r b c L$ (N.P) } & \multicolumn{7}{|c|}{$\operatorname{trn} L-\operatorname{trn} F(\mathrm{~N} . \mathrm{P})$} & & & & & & & \\
\hline & 247 & 261 & 600 & 654 & 681 & 705 & 752 & 771 & 793 & & & & & & & \\
\hline $12-\mathrm{S}$ & $\mathrm{C}$ & $\mathrm{T}$ & $\mathrm{T}$ & $\mathrm{G}$ & A & $\mathrm{T}$ & A & $\mathrm{T}$ & G & & & & & & & \\
\hline $12-\mathrm{H}$ & $\mathrm{C}$ & $\mathrm{T}$ & $\mathrm{T}$ & G & A & $\mathrm{T}$ & A & $\mathrm{T}$ & G & & & & & & & \\
\hline $63-\mathrm{H}$ & $\mathrm{C}$ & $\mathrm{T}$ & $\mathrm{C}$ & G & G & $\mathrm{T}$ & A & $\mathrm{T}$ & G & & & & & & & \\
\hline $85-\mathrm{S}$ & $\mathrm{T}$ & $\mathrm{T}$ & $\mathrm{C}$ & G & G & $\mathrm{T}$ & A & $\mathrm{T}$ & G & & & & & & & \\
\hline T. fargesii & $\mathrm{C}$ & $\mathrm{C}$ & $\mathrm{T}$ & G & A & $\mathrm{C}$ & - & $\mathrm{T}$ & G & & & & & & & \\
\hline T. grandis & $\mathrm{C}$ & $\mathrm{C}$ & $\mathrm{T}$ & $\mathrm{T}$ & A & $\mathrm{C}$ & - & $\mathrm{T}$ & A & & & & & & & \\
\hline T. jackii & $\mathrm{C}$ & $\mathrm{T}$ & $\mathrm{T}$ & G & A & $\mathrm{T}$ & - & G & G & & & & & & & \\
\hline \multirow[t]{2}{*}{ Sample } & \multicolumn{16}{|c|}{$p s b A-t r n H$ (N.P) } \\
\hline & 441 & 444 & 445 & 457 & 486 & 552 & 572 & 573 & 574 & 575 & 576 & 624 & 627 & 628 & 639 & 644 \\
\hline $12-S$ & $\mathrm{~T}$ & A & G & $\mathrm{T}$ & G & $\mathrm{T}$ & $\mathrm{T}$ & A & G & A & $\mathrm{C}$ & A & G & G & $\mathrm{C}$ & $\mathrm{T}$ \\
\hline $12-\mathrm{H}$ & $\mathrm{T}$ & A & G & $\mathrm{T}$ & G & $\mathrm{T}$ & $\mathrm{T}$ & A & G & A & $\mathrm{C}$ & A & G & G & $\mathrm{C}$ & $\mathrm{T}$ \\
\hline $63-\mathrm{H}$ & $\mathrm{T}$ & A & G & $\mathrm{T}$ & G & $\mathrm{T}$ & $\mathrm{T}$ & A & G & A & $\mathrm{C}$ & A & G & G & $\mathrm{C}$ & $\mathrm{T}$ \\
\hline $85-\mathrm{S}$ & $\mathrm{T}$ & A & G & $\mathrm{T}$ & G & $\mathrm{T}$ & $\mathrm{T}$ & A & G & A & $\mathrm{C}$ & A & G & G & $\mathrm{C}$ & $\mathrm{T}$ \\
\hline T. fargesii & $\mathrm{T}$ & A & G & $\mathrm{T}$ & A & $\mathrm{C}$ & $\mathrm{T}$ & A & G & A & $\mathrm{C}$ & A & G & G & $\mathrm{C}$ & $\mathrm{C}$ \\
\hline T. grandis & $\mathrm{T}$ & G & $\mathrm{T}$ & $\mathrm{C}$ & A & $\mathrm{T}$ & $\mathrm{T}$ & A & G & A & $\mathrm{C}$ & A & G & G & $\mathrm{C}$ & $\mathrm{T}$ \\
\hline T. jackii & $\mathrm{C}$ & A & G & $\mathrm{T}$ & A & $\mathrm{T}$ & - & - & - & - & - & $\mathrm{T}$ & $\mathrm{T}$ & - & - & $\mathrm{T}$ \\
\hline
\end{tabular}

N.P nucleotide position

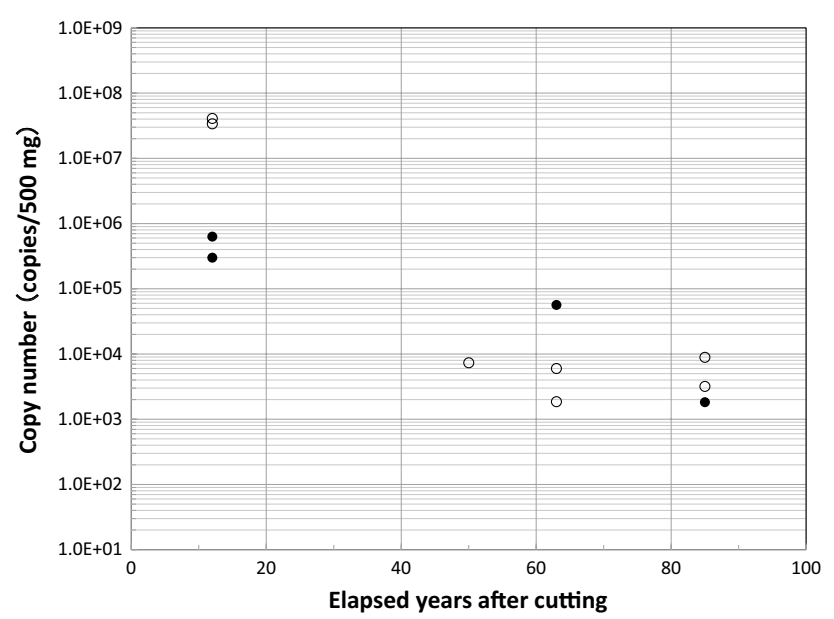

Fig. 2 Relationship between elapsed years after cutting and copy numbers of $99 \mathrm{bp} r b c L$ fragments. Open circle sapwood, closed circle heartwood

and then analyzed in order to set the appropriate amplified regions for DNA identification among the wood of Torreya species.

\section{Evaluation of copy numbers of plastid DNA fragments}

Figure 2 shows the relationship between the elapsed years after cutting and the copy numbers of the $99 \mathrm{bp} r b c L$ fragment. The copy numbers for $12-\mathrm{S}$ were estimated to be $3.38 \times 10^{7}$ and $4.08 \times 10^{7}$ copies $/ 500 \mathrm{mg}$, respectively. The copy numbers for $12-\mathrm{H}$ were estimated to be $3.00 \times 10^{5}$ and $6.30 \times 10^{5}$ copies $/ 500 \mathrm{mg}$, respectively, approximately onehundredth of those for 12-S. The $99 \mathrm{bp}$ rbcL fragment was not clearly detected for 50-S and 50-H, which corresponded to the results of PCR amplifications shown in Fig. 1a. This qPCR analysis detected the $99 \mathrm{bp}$ fragment for 63-S, although the $370 \mathrm{bp}$ fragment was not amplified. Their copy numbers were estimated to be approximately one tenthousandth of those for 12-S. Conversely, the copy number was not clearly estimated for $63-\mathrm{H}$. Almost the same copy numbers were obtained for $85-\mathrm{S}$, but the copy number was not clearly estimated for $85-\mathrm{H}$.

Figure 3 shows the relationship between the elapsed years after cutting and the copy numbers of the $111 \mathrm{bp}$ trnL-trnF fragment. The copy numbers for $12-\mathrm{S}$ were estimated to be $9.44 \times 10^{7}$ and $8.40 \times 10^{7}$ copies $/ 500 \mathrm{mg}$, respectively. The copy numbers for $12-\mathrm{H}$ were approximately one-hundredth of those for $12-\mathrm{S}$. For these two samples, almost the same results were obtained between the $\operatorname{trn} L-t r n F$ fragment and the $r b c L$ one. The copy numbers were estimated for $63-\mathrm{S}$ and $85-\mathrm{S}$ as in the case of the $r b c L$ fragments. The copy numbers were also estimated for 50-H. Figure 4 shows the relationship between the elapsed years after cutting and the copy numbers of the 93 bp psbAtrnH fragment. The copy numbers for $12-\mathrm{S}$ were estimated to be $9.62 \times 10^{6}$ and $9.01 \times 10^{6}$ copies $/ 500 \mathrm{mg}$, respectively, which were slightly smaller compared with the results for the other two fragments. Similar results were obtained for $12-\mathrm{H}$. The $93 \mathrm{bp}$ fragment was not detected for $50-\mathrm{H}$ 


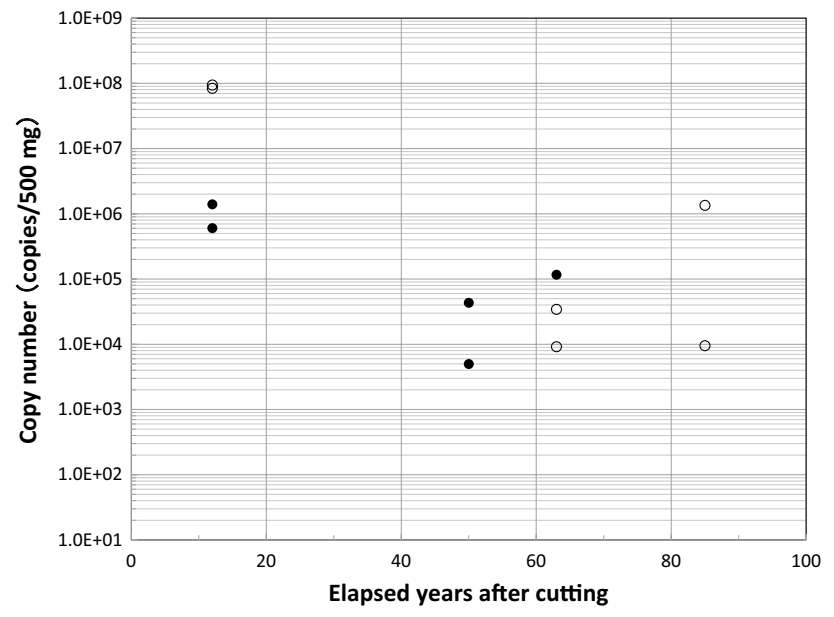

Fig. 3 Relationship between elapsed years after cutting and copy numbers of 111 bp trnL-trnF fragments. Open circle sapwood, closed circle heartwood

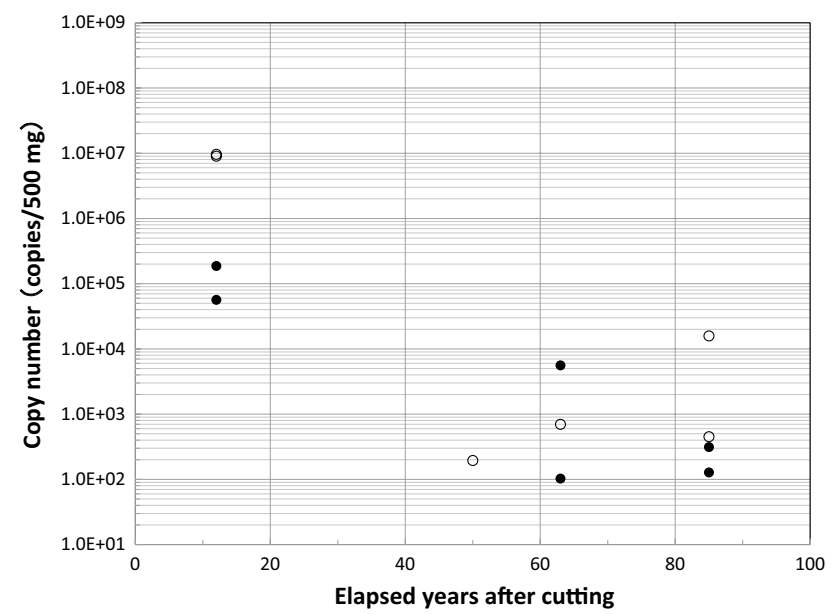

Fig. 4 Relationship between elapsed years after cutting and copy numbers of 93 bp psbA-trnH fragments. Open circle sapwood, closed circle heartwood

in contrast with PCR amplification of the $379 \mathrm{bp}$ fragment shown in Fig. 1c. The copy numbers were also estimated for $63-\mathrm{H}$. The $93 \mathrm{bp}$ fragment was detected for $85-\mathrm{H}$, although the $379 \mathrm{bp}$ fragment was not amplified.

The qPCR analyses in this study generally estimated the amounts of plastid DNA fragments stored in the T. nucifera sapwood. The results shown in Figs. 1, 2, 3, and 4 suggest that the residual amounts of fragments in the sapwood scarcely depend on regions in the plastid genome. Copy numbers of the fragments decreased significantly in wood specimens cut over 50 years ago. It is considered that the plastid DNA in the T. nucifera sapwood has been fragmented with more elapsed years after cutting, but fragments with a length of approximately $100 \mathrm{bp}$ have remained in the old sapwood materials. Conversely, it was difficult to detect the residual fragments of plastid DNA in the $T$. nucifera heartwood with longer elapsed years after cutting, which could be attributed to their unstable amplifications. Analyzing the $\operatorname{trnL}-\operatorname{trn} F$ and $p s b A$-trnH intergenic spacers on plastid DNA has functioned in the detailed discrimination of woody plants, such as their molecular evolutionary history [18], genetic relationship among cultivars [19], geographic distribution [20], climatic niche dynamics [21], and phylogeographic structure [22, 23]. In the conifer II clade that contains the five families except Pinaceae, plastid genomic organization relatively varies due to both the loss of inverted repeat and the shrinkage of intergenic spacers [24], which can be strongly related to the DNA identification of wood in the same genus. For Torreya sp. investigated in this study, the shrinkage of $p s b A-t r n H$ intergenic spacer was observed, as shown in Table 4. Detecting a small number of nucleotide substitutions and deletions in the intergenic spacers on plastid DNA with a high degree of accuracy may enable the identification of wood species used in the single-bole statues.

\section{Separation of wood of $T$. nucifera and T. grandis using DNA analysis}

It has been clarified that the woods of Torreya spp. were used for many single-bole statues produced in the period from the 8th to ninth centuries, such as the standing statues of Shitenno (Daian-ji temple), Yakushinyorai (Jingoji temple), Den-yakushinyorai (Toshodai-ji temple), and Den-shuhououbosatu (Toshodai-ji temple) [3, 4]. Jianzhen visited Japan to teach the Chinese Buddhist precepts in the mid-eighth century. He also built Toshodai-ji temple in Nara as a place for Buddhist training, where the representative single-bole statues are enshrined as mentioned above. Actually, the number of single-bole statues made of the wood of Torreya sp. increased after his arrival. From these historical facts, it is inferred that Jianzhen and his party introduced and directed the production of statues with wood of this genus [3]. The following three processes are considered for the transition of production of statues: (1) the statues were carved in China and brought to Japan; (2) wood materials were brought to Japan from China, and the statues were carved in Japan; and (3) the statues were carved in Japan with the wood of Japanese Torreya sp. Jianzhen was also a Buddhist monk at Daming temple in Yangzhou, Jiangsu, China before his arrival in Japan. Jiangsu is one of the vegetation areas of $T$. grandis. This fact suggests a possibility that wood of this species had been introduced to Japan for making single-bole statues, at least in the mid-eighth century. Therefore, the wood identification between $T$. nucifera and $T$. grandis is a priority task in studying the major historical change of wooden Buddhist statues in Japan. 
Plastid DNA sequences of $T$. nucifera and $T$. grandis exhibit relatively high homology to each other (Table 4), indicating that targeted regions should be carefully chosen from intergenic spacers to identify the wood of the genus Torreya based on the differences in plastid DNA sequences. For example, the results obtained by nucleotide sequencing in this study show that the difference in nucleotide at position 486 for $p s b A$-trnH provides a distinction of wood between T. nucifera and Torreya sp. in China. Comparing the nucleotides at positions 654 and 793 in $\operatorname{trnL}-\operatorname{trnF}$ and at positions 444, 445 and 457 in psbA-trnH enables the clear identification of wood between T. nucifera and T. grandis. This study demonstrates that plastid DNA fragments can be detected from the wood of T. nucifera placed in a room under stable conditions such as in a xylarium, although their PCR amplifications are somewhat unstable. The previous study indicated that residual plastid DNA in old wood materials was fragmented to a length of approximately 200 bp [15]. Wooden Buddhist statues that are registered as important cultural assets are being placed under constant conditions of temperature, humidity, and light to avoid the decay of the wood. Therefore, quite small amounts of plastid DNA fragments with a length of 100 to $200 \mathrm{bp}$ are considered to remain in old wooden Buddhist statues. For practical application, a more efficient extraction of residual DNA and the detection of targeted sequences with higher accuracy and sensitivity are required for the identification of wood species used for statues, as only a small amount of wood pieces is collected. Sonication under an approximate condition may effectively extract the residual DNA from a small amount of thin wood sections or wood powder. Digital PCR system, a system for absolute quantification of DNA copy number, is considered to function in detecting the targeted DNA fragment stored in old wood [25]. Although there are remaining issues to be solved, a combined method of these two techniques will enable the DNA identification of wood used for the Buddhist statues in the eighth and ninth centuries.

\section{Conclusion}

This study conducted the extraction of residual DNA from the sapwood and heartwood of T. nucifera with different elapsed years after cutting, sequence analyses of their plastid DNA fragments, and an evaluation of their residual amounts. Nucleotide substitutions and deletions in plastid DNA sequences were clearly determined between $T$. nucifera and the species distributed in China, which could be the basis for discrimination among these woods. The results obtained by DNA polymorphism analyses exhibited sequence diversity of the intergenic spacers on the $T$. nucifera plastid DNA, indicating that more sequence data of the plastid DNA should be collected and analyzed to set the appropriate amplified regions for wood identification. The PCR amplification of plastid DNA fragments was unstable for the T. nucifera heartwood with longer elapsed years after cutting, whereas fragments with a length of approximately $100 \mathrm{bp}$ were considered to be amplified for the sapwood. Multiple sequence analyses for intergenic spacers on plastid genome are considered to ensure the accurate discrimination of wood of T. nucifera from those of Chinese Torreya spp. Although there are remaining issues to be solved for practical application, DNA identification of the wood of Torreya spp. is considered to be a feasible measure to accurately identify the materials used for Buddhist statues after the mid-eighth century. The characteristics of statues strongly reflect an outlook on Buddhism during the period when the statues were produced. The choice of wood and the style of sculpture thus play key roles in the characterization of Buddhist statues. Therefore, DNA identification will contribute significantly to studies on the styles of wooden Buddhist statues.

Acknowledgements This research was supported by a Grant-in-Aid for Scientific Research (No. 25292109) from the Japan Society for the Promotion of Science (JSPS).

\section{References}

1. Eckenwalder JE (2009) Conifer genera and species. Conifers of the world, the complete reference. Timber Press, Portland, pp 612-619

2. Farjon A (2010) Taxonomic treatment of genera and species. A handbook of the world's conifers. vol II. Brill, Leiden-Boston, pp 998-1006

3. Kaneko H, Iwasa M, Noshiro S, Fujii T (1998) Wood types and material selection for Japanese wooden statues of the ancient period (particularly the 7th-8th century) (in Japanese with English summary). Museum 555:3-54

4. Abe H, Watanabe K, Ishikawa A, Noshiro S, Fujii T, Iwasa M, Kaneko H, Wada H (2016) Simple separation of Torreya nucifera and Chamaecyparis obtusa wood using portable visible and near-infrared spectrophotometry: differences in light-conducting properties. J Wood Sci 62:210-212

5. IAWA Committee (2004) IAWA list of microscopic features for softwood identification. IAWA J 25:1-70

6. Abe H, Watanabe U, Yoshida K, Kuroda K, Zhang C (2011) Changes in organelle and DNA quality, quantity and distribution in the wood of Cryptomeria japonica over long-term storage. IAWA J 32:263-272

7. Ohyama M, Baba K, Itoh T (2001) Wood identification of Japanese Cyclobalanopsis species (Fagaceae) based on DNA polymorphism of the intergenic spacer between $\operatorname{trn} \mathrm{T}$ and $\operatorname{trn} \mathrm{L} 5^{\prime}$ exon. J Wood Sci 47:81-86

8. Dumolin-Lapegue S, Pemonge M-H, Gielly L, Taberlet P, Petit RJ (1999) Amplification of oak DNA from ancient and modern wood. Mol Ecol 8:2137-2140

9. Tsumura Y, Kado T, Yoshida K, Abe H, Ohtani M, Taguchi Y, Fukue Y, Tani N, Ueno S, Yoshimura K, Kamiya K, Harada K, Takeuchi Y, Diway B, Finkeldey R, Na'iem M, Indrioko S, Ng KKS, Muhammad N, Lee SL (2011) Molecular database for 
classifying Shorea species (Dipterocarpaceae) and techniques for checking the legitimacy of timber and wood products. J Plant Res 124:35-48

10. Deguilloux M-F, Pemonge M-H, Petit RJ (2002) Novel perspectives in wood certification and forensics: dry wood as a source of DNA. Proc R Soc Lond Ser Biol Sci 269:1039-1046

11. Asif MJ, Cannon CH (2005) DNA extraction from processed wood: A case study for the identification of an endangered timber species (Gonystylus bancanus). Plant Mol Biol Rep 23:185-192

12. Rachmayanti Y, Leinemann L, Gailing O, Finkeldey R (2006) Extraction, amplification and characterization of wood DNA from Dipterocarpaceae. Plant Mol Biol Rep 24:45-55

13. Rachmayanti Y, Leinemann L, Gailing O, Finkeldey R (2009) DNA from processed and unprocessed wood: factors influencing the isolation success. Forensic Sci Int Genet 3:185-192

14. Librado P, Rozas J (2009) DnaSP v5: a software for comprehensive analysis of DNA polymorphism data. Bioinformatics 25:1451-1452

15. Watanabe U, Abe H, Yoshida K, Sugiyama J (2015) Quantitative evaluation of properties of residual DNA in Cryptomeria japonica wood. J Wood Sci 61:1-9

16. Buchanan BB, Gruissem W, Jones RL (2000) Nucleic acids. Biochemistry and molecular biology of plants. American society of plant biologists, Maryland, pp 282-291

17. Hirao T, Watanabe A, Kurita M, Kondo T, Takata K (2008) Complete nucleotide sequence of the Cryptomeria japonica D. Don. chloroplast genome and comparative chloroplast genomics: diversified genomic structure of coniferous species. BMC Plant Biol 8:70. doi:10.1186/1471-2229-8-70

18. Mustapha SB, Tamarzizt HB, Baraket G, Abdallah D, Hannachi AS (2015) Cytoplasmic polymorphism and evolutionary history of plum cultivars: Insights from chloroplast DNA sequence variation of $t r n \mathrm{~L}-t r n \mathrm{~F}$ spacer and aggregated $\operatorname{trn} \mathrm{L}$ intron \& $\operatorname{trn} \mathrm{L}$ trnF spacer. Genet Mol Res 14:3964-3979

19. Mustapha SB, Tamarzizt HB, Baraket G, Abdallah D, Hannachi AS (2015) Genetic diversity and differentiation in Prunus species (Rosaceae) using chloroplast and mitochondrial DNA CAPS markers. Genet Mol Res 14:4177-4188

20. Chen SC, Zhang L, Zeng J, Shi F, Yang H, Mao YR, Fu CX (2012) Geographic variation of chloroplast DNA in Platycarya strobilacea (Juglandaceae). J Syst Evol 50:374-385

21. Koecke AV, Muellner-Riehl AN, Pennington TD, Schorr G, Schnitzer J (2013) Niche evolution through time and across continents: the story of neotropical Cedrela (Meliaceae). Am J Bot 100:1800-1810

22. Li XH, Shao JW, Lu C, Zhang XP, Qiu YX (2012) Chloroplast phylogeography of a temperate tree Pteroceltis tatarinowii (Ulmaceae) in China. J Syst Evol 50:325-333

23. Budde KB, González-Martínez SC, Hardy OJ, Heuertz M (2013) The ancient tropical rainforest tree Symphonia globulifera $\mathrm{L}$. $\mathrm{f}$. (Clusiaceae) was not restricted to postulated Pleistocene refugia in Atlantic Equatorial Africa. Heredity 111:66-76

24. Wu CS, Chaw SM (2014) Highly rearranged and size-variable chloroplast genomes in confers II clade (cupressophyte): evolution towards shorter intergenic spacers. Plant Biotech $\mathrm{J}$ 12:344-353

25. Hindson BJ, Ness KD, Masquelier DA, Belgrader P, Heredia NJ, Makarewicz AJ, Bright IJ, Lucero MY, Hiddessen AL, Legler TC, Kitano TK, Hodel MR, Petersen JF, Wyatt PW, Steenblock ER, Shah PH, Bousse LJ, Troup CB, Mellen JC, Wittmann DK et al (2011) High-throughput droplet digital PCR system for absolute quantification of DNA copy number. Anal Chem $83: 8604-8610$ 